\title{
Household sustainable behavior evaluation and its relationship with socioeconomic indicators in the city of Guayaquil.
}

\author{
José Hidalgo, MSc. ${ }^{1}$, Tania Crespo, Mg. ${ }^{1}$, Silvia Coello, Mg. ${ }^{1}$, and Yomar González, PhD. ${ }^{1}$ \\ ${ }^{1}$ Universidad de Guayaquil, Ecuador, jose.hidalgocr@ug.edu.ec, tcrespo2@hotmail.com,silvia.coellop@ug.edu.ec, \\ yomar.gonzalezc@ug.edu.ec
}

\begin{abstract}
In order to deal with global warming and climate change through the smart management of natural resources and waste elimination for the conservation of the environment, this study aims to evaluate the behavior of household's residents towards electricity and water consumption and solid waste generation (HSW). The paper also intends to correlate this behavior with socioeconomic indicators, such as: household size, level of education, income generation, labor force and social status. This study relied on 2593 random stratified questionnaires who live in the city of Guayaquil. The findings revealed that different socioeconomic groups houses demonstrate the same tendency in the sustainable consumption attitudes of electricity of water. Subsequently, the findings also ascertained differences are found in the possession of ecological devices. HSEG possess more these kinds of devices than LSEG. Therefore, government strategies should be set in motion to make households more aware of the level of pollution they produce and the inefficacy of their consumption of resources.
\end{abstract}

\section{INTRODUCTION}

The growing demand of electricity and water in households to maintain a certain level of comfort is generating great pressure on its generation, and with that, the deterioration of the ecosystem. Therefore, [1] the misuse of these resources in the home is a serious problem. To solve this problem, there are two courses of action available: a) increase the generation of electricity and water through clean technologies, which can be very costly in the short and medium term or b) decrease the demand for the service, in other words, support a change in the lifestyles and habits of the people that promotes a better care of consumption, meaning a sustainable consumption.

Also, the management of household solid waste (HSW) has become a serious problem for many countries, particularly for developing countries in which the demographic growth implies an increment in the solid waste generation [2]. In addition, the deficient educational system and little community participation in the city results in a lack of cleanliness and visual contamination of the environment [3].

The Ecuadorian Constitution in its in Section II Article 14 states the rights of nature as follows, "The right of the population to live in a healthy and ecologically balanced environment, which guarantees sustainability and good health, is recognized [4].

Digital Object Identifier (DOI):

http://dx.doi.org/10.18687/LACCEI2019.1.1.55

ISBN: 978-0-9993443-6-1 ISSN: 2414-6390
Furthermore, "it is declared of public interest the preservation of the environment, the conservation of ecosystems, biodiversity and the integrity of the country's genetic heritage, the prevention of environmental damage and the recovery of natural areas degraded".

According to statistical data collected from the National Institute of Statistics and Censuses (INEC) in 2017; approximately 16.62 million people live in Ecuador, from which $15 \%$ belong to the city of Guayaquil. Based on the information provided by the Ministry of the Environment, it was determined that each inhabitant of Ecuador in the urban sector produces an average of $0.58 \mathrm{~kg} /$ inhabitant/day of solid waste, of which 53\% are organic [5]. Although, a recent study [6] for the city of Guayaquil, shows that the average rate of household solid waste generation in the city of Guayaquil is $0.72 \mathrm{~kg} / \mathrm{capita} /$ day and $18 \%$ of that is non-biodegradable.

\section{Electrical Sustainability}

[7] found a relationship between attitude to energy consumption and household energy consumption, and that the sociological variables explained more than $60 \%$ of total variation in household energy consumption. Data analysis on electricity consumption for lighting and appliances suggest that, [8] this is more dependent on user practices than on energy efficiency, especially if the number of appliances are counted as part of the user practice.

There is also a strong influence of certain socioeconomic factors in the electricity consumption. [9] found a relation between electricity per capita and household size, level of education, household labour force, income and utility. Also, consumers' adoption to the efficient usage of energy varies depending on demographic, behavioral and situational dynamics in their households and societies [10].

\section{Water Sustainability}

Water usage in our society cannot be called sustainable, since to much purified water is taken by the system and much polluted water is discharged in the local rivers and a major part of this problem is the household use of this resource. [11] mentions the reuse or recycling of domestic water could lead to big reductions. Some studies [12] show a relationship with socioeconomic demographics and water end use consumption levels. [13] exposes that trust plays a role in household water

$17^{\text {th }}$ LACCEI International Multi-Conference for Engineering, Education, and Technology: "Industry, Innovation, And

Infrastructure for Sustainable Cities and Communities", 24-26 July 2019, Jamaica. 
consumption, since people will not save water if they feel others are not minimizing their water use (inter-personal trust).

\section{Waste Generation Sustainability}

Despite some advances towards enhancing environmental protection, rapid urbanization and inequality in the developing world makes the collection of MSW even more difficult. To plan a MSW management strategy for a given city, it is essential to know the quantity of waste generated and its composition. The knowledge of how much and what solid waste is generated is acquired based on studies of classification of solid waste at the level of populated complexes or districts; establishing in those studies how much each inhabitant generates per day, the density of the waste, the estimated generation and the specific composition of solid waste.

Several studies have been conducted on correlating socioeconomic characteristics with HSW generation. Some researchers have established that income, household size and household labor force can change the consumption patterns of households, resulting in changed composition and quantities of household waste [13] [14]. Other authors [15] [16] found that the solids per capita generation decreases with decreasing social status and solid waste composition showed variations due to the change in social status. [17] indicated that there was no much difference in the composition of wastes among different socioeconomic groups except ash residue and plastic. Further, [18] found that residential solid waste generation such as food, paper, plastic and metal showed significant positive correlation with family size. [19] showed the relevance of considering social aspects, such as level of education in municipal solid waste management.

The objectives of this investigation were to determine the following:

1. To evaluate the behavior of household residents over sustainable consumption of electricity and water;

2. To examine the habits of consumption of goods and the expected amount of solid waste; and

3. To find the ways these behaviors ad habits change with the social status of the house.

Results from this study will provide inputs to the environmental management planners in their decision making towards effective and sustainable household management systems for Guayaquil city.

\section{THE STUDY AREA}

Guayaquil is the largest and most populated city in Ecuador with around 2.70 million people in the metropolitan area. As the nation's principal commercial and manufacturing center, Guayaquil is located on the western bank of the Guayas River and is the capital of the Ecuadorian province of Guayas.
As the focus of Ecuador's international trade and domestic commerce, it is economically the country's most important city. There are sugar refineries, iron foundries, machine shops, tanneries, and sawmills, as well as fabricating and processing plants for a variety of light consumer goods. Industrial development has resulted in population growth greater than that of Quito (with which a distinct rivalry exists), and the largescale immigration of rural workers has confronted the city with the problem of growing slum areas.

This city shows much variation with respect to socioeconomic conditions and it's considered to be representative for the province of Guayas. According to the last census of population and housing [12] taken in 2010, there were almost 413 thousand households, located mostly in the southwest of the city $(35 \%)$ and northeast $(28 \%)$, followed by southeast $(25 \%)$ and finally the northeast $(12 \%)$.

\section{METHODOLOGY}

The measurement of sustainability behavior of each household consisted of the following steps:

\section{Calculation of number of samples}

Household consumption of resources, such as electricity and water, and generation of solid waste varies from place to place and from social status. To estimate with precision the habits, it was necessary to execute a statically designed sampling survey. Logically, the accuracy of the sampling would increase with the number of samples; nevertheless, this number had to be restricted due to the available resources.

The procedure used to determine the minimum number of samples needed to gather reasonably accurate data was based on the central limit theorem. The number of samples was determined with a $99 \%$ confidence interval and a 2,6\% standard error, for a population of 413 thousand households, using the following equation:

$$
n=\frac{k^{2} * p * q * N}{e^{2} *(N-1)+k^{2} * p * q}
$$

where $\mathrm{n}$ is the minimum number of samples, $\mathrm{k}$ is a constant that depends on the level of confidence (for $99 \%$ confidence $\mathrm{k}$ is $2.575)$, e is the sampling error $(2,6 \%), \mathrm{p}$ is the proportion of inhabitants that possess the characteristic we seek, and $q$ is the number of inhabitants that don't possess it (For this case is 0.5 for each one).

After using this equation, the number of households needed to obtain a $2,6 \%$ standard error with $99 \%$ level of confidence is 2438 .

$17^{\text {th }}$ LACCEI International Multi-Conference for Engineering, Education, and Technology: "Industry, Innovation, And Infrastructure for Sustainable Cities and Communities", 24-26 July 2019, Jamaica. 


\section{Information collection procedure}

For determination of the habits and its influence of social status, a general course project was elaborated for students of two local universities of the city. A total of 140 students participated between both universities, each of them with ten households including their own ( 9 neighbors + own home). They were given two questionnaires, one to measure the social status and the other to acquire information of socioeconomic factors and attitudes towards sustainability.

The duration of the project was two months, to give them enough time and to get precise information. Questionnaires were administered to their own neighbors and given there were plenty of students a significant and well distributed sample was acquired. The step by step procedure to register the data by the students was as follows:

1. Students were instructed in the project and given 20 questionnaires, one pair per household (10 of social status and 10 of household sustainability).

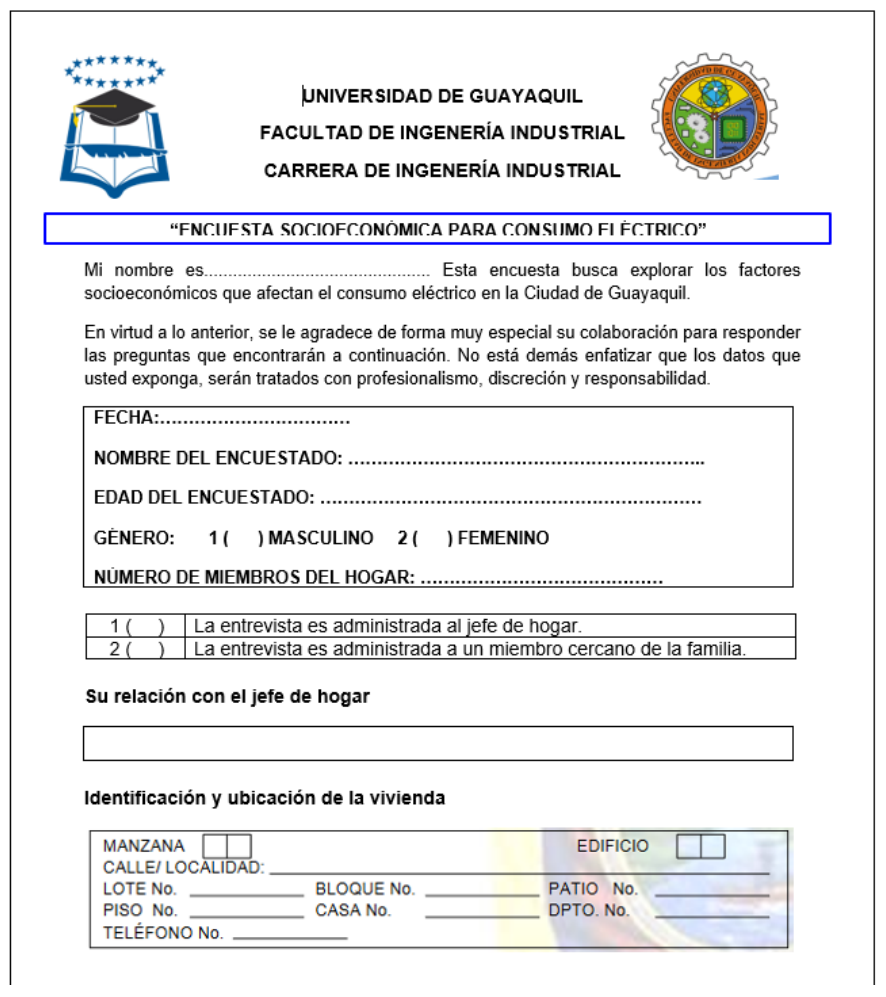

Fig. 1 Sample sheet format for weigh collection.

2. Students took the survey to each household and registered all the information in the sample sheet.

The questionnaire was administrated to 2.593 selected representative households to obtain information about their socio-economic factors such as household size (HS), level of income (LI), social status (SS), labor force (HL) and mideducation level (HE) and habits of consumption and waste generation.

Questions 1 to 10 were about electricity sustainable use as follows:

Q1: Do you disconnect electronic devices and appliances when you do not use them or leave the house?

Q2: Do you turn off the lights when leaving a room?

Q3: Do you introduce hot meals in the fridge?

Q4: Do you iron as many clothes as possible in one go?

Q5: Do you open curtains and blinds to take advantage of sunlight?

Q6: Do you have energy savings household appliances (refrigerator, washing machine, dryer)?

Q7: Do you have solar panels?

Q8: Do you use the microwave, toaster and vacuum as little as possible?

Q9: Do you maintain equipment, appliances and electrical installations?

Q10: Do you gather clothes to use the washing machine less often?

Questions 11 to 18 were about water sustainable use as follows:

Q11: Do you reuse water (To scrub, water, throw to the bathroom)?

Q12: Do you use a bucket instead of a hose for certain activities (washing a vehicle, watering garden plants, etc.)?

Q13: Do you close your faucets while soaping dishes, bathing, brushing your teeth, etc.?

Q14: Do you shower in less than 10 minutes?

Q15: Do you regularly check the water pipes?

Q16: Do you have jet economizers (water flow reducers)?

Q17: Do you have a double flush toilet?

Q18: Do you place a bottle or other object inside the toilet water tank?

To research the organic paper waste produced, the frequency of newspaper and catalogs were asked. To know the production of other wastes such as plastics, metals, cardboard and glass, it was asked the weekly frequency of acquirement of this type of products.

Also, the households in study area were stratified into five different socio-economic groups based on a stratification questionnaire about income, owned electronic devices, types of jobs and others. This questionnaire measures the socioeconomic group on a scale from 0 to 1000.

- Low socio-economic group: threshold < 316 (LSEG)

- Middle low socio-economic group: threshold between 316,1 - 535 (MLSEG)

$17^{\text {th }}$ LACCEI International Multi-Conference for Engineering, Education, and Technology: "Industry, Innovation, And Infrastructure for Sustainable Cities and Communities", 24-26 July 2019, Jamaica. 
- Middle socio-economic group: threshold between 535,1 - 696 (MSEG)

- Upper middle socio-economic group: threshold between 696,1 - 845 (UMSEG)

- High socio-economic group: threshold between 845,1 -1000 (HSEG)

\section{RESULTS}

A total of 2.593 households from the city of Guayaquil were selected randomly for the study. The city was divided into 4 sectors and $18 \%$ came from the Southeast, $14 \%$ from the Northeast, 25\% from Southwest and almost $44 \%$ from the Northwest as shown in Fig. 2.

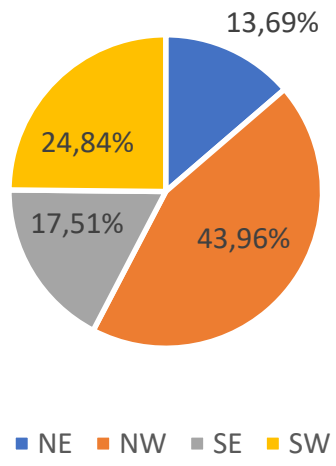

Fig. 2 Household stratification per city zone.

\section{Socio-economic characteristics of households}

An essential preliminary step in household behavior towards sustainability is the accurate estimation of several socioeconomic parameters, because these, affect the consumption of resources such as electricity and water, also the generation of waste. These include education level, monthly income, number of members, social status, age composition and labor force. Fig. 3 shows the number of members per household, as it can been seen, it shows a normal distribution and has an average of 3,76 members per household.

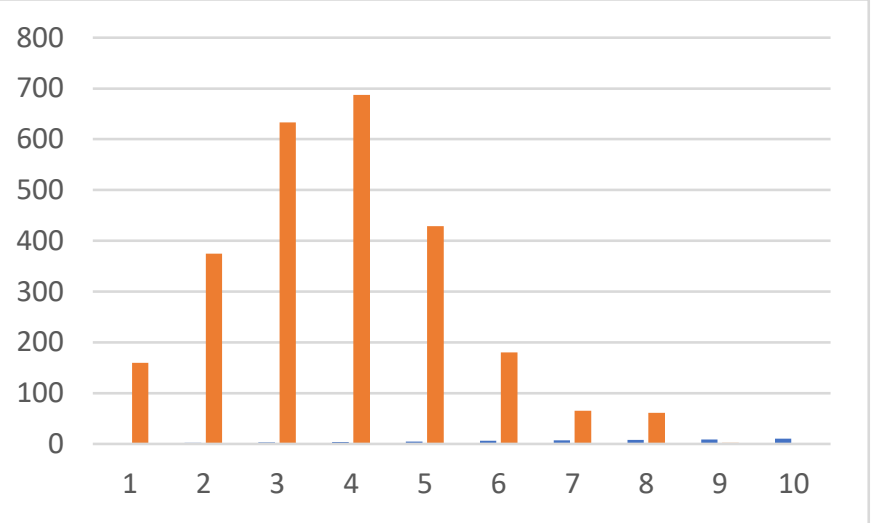

Fig. 3 Number of members per household histogram. Mean $=3.76$ members per household

Also, figure 4 presents the socio-economic demographic of the city of Guayaquil. Only 6,59\% of the population belong to the high social class and $0,66 \%$ to the low social class. The remaining of households $(93 \%)$ are divided between middle low, middle and upper middle social class. This figure demonstrates that most of the population is in the middle-class groups. Fig. 5, delivers instead the stratification of social status among all the 4 zones of the study. Most of the MSEG households (19,5\%) are located in the northwest, whilst 0,27\% of LSEG households live in southwest of the city.

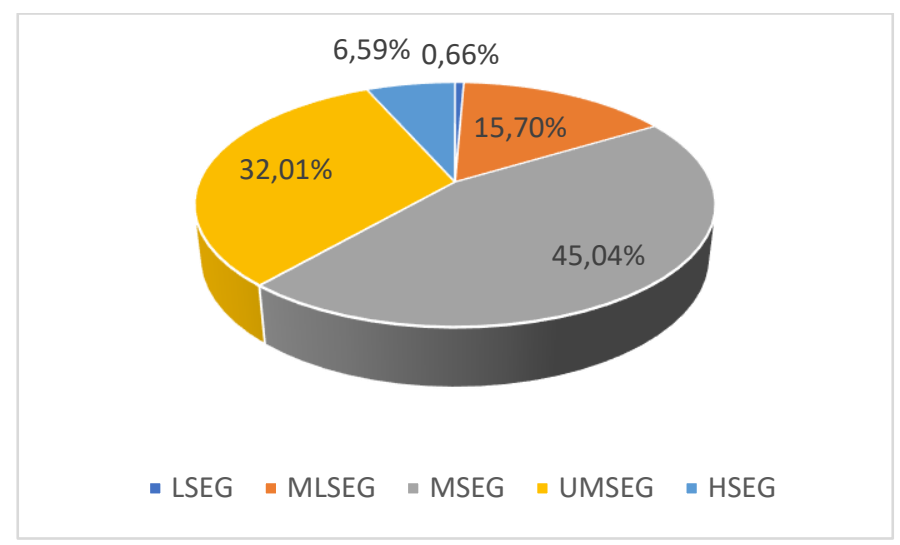

Fig. 4 Percentage of households by socio-economic group.

One surprise factor for this research can be seen in figure 6 , where the average number of household members increase with the socioeconomic status. An average of 3,98 members habit in HSEG houses whilst 2,47 members live in LSEG, totally unexpected since it's believed that the less rich tend to have more children. The figure shows also that MLSEG, MSEG and UMSEG have 3,40,3,77 and 3,90 average members respectively. Given this research only applies to households and not to homeless people, this figure could change if they were included.

$17^{\text {th }}$ LACCEI International Multi-Conference for Engineering, Education, and Technology: "Industry, Innovation, And Infrastructure for Sustainable Cities and Communities", 24-26 July 2019, Jamaica. 


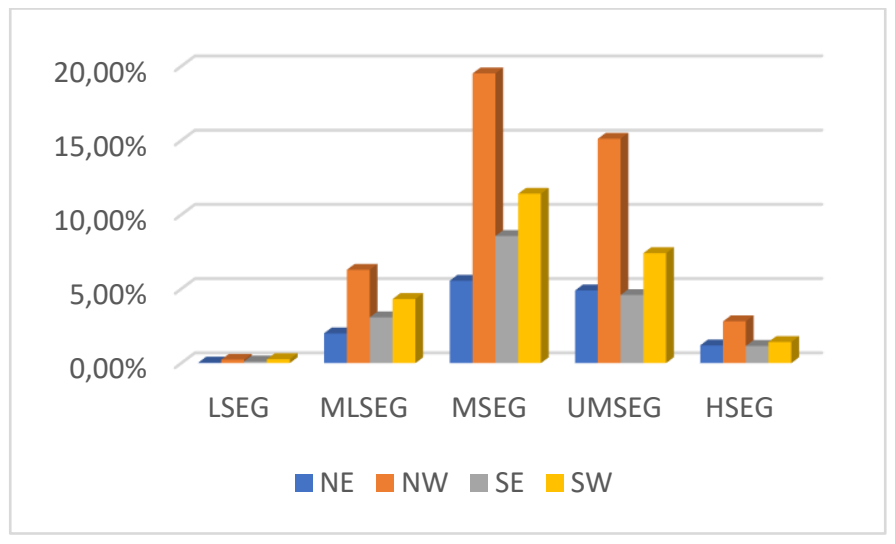

Fig. 5 Stratification of socio-economic groups among the 4 zones of the study.

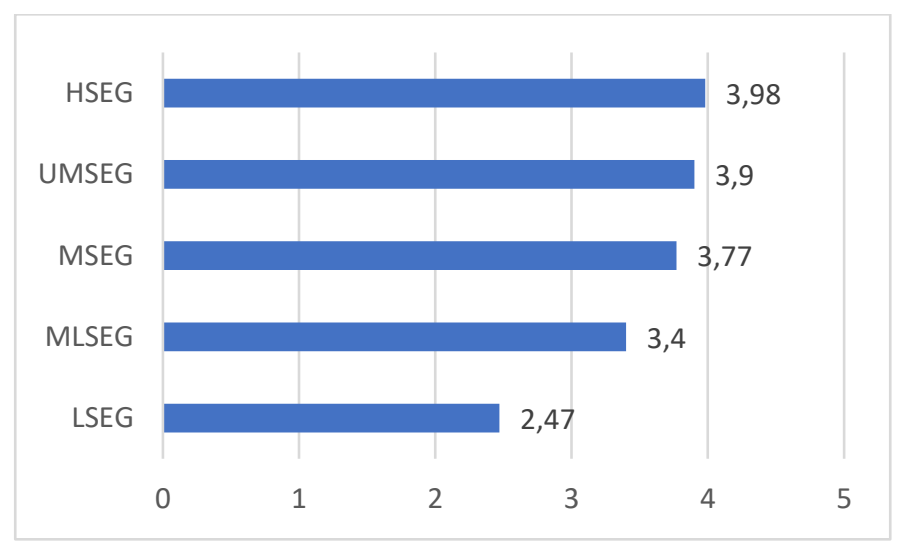

Fig. 6 Average number of family members by of socioeconomic groups.

Fig. 7, shows the age distribution among socioeconomic groups, where we can see that for all social status houses there are more people between 26 and 50 years old. The figure presents a normal distribution being the lowest values for the elderly (older than 65 years old) and younger members (less than 12 years old)

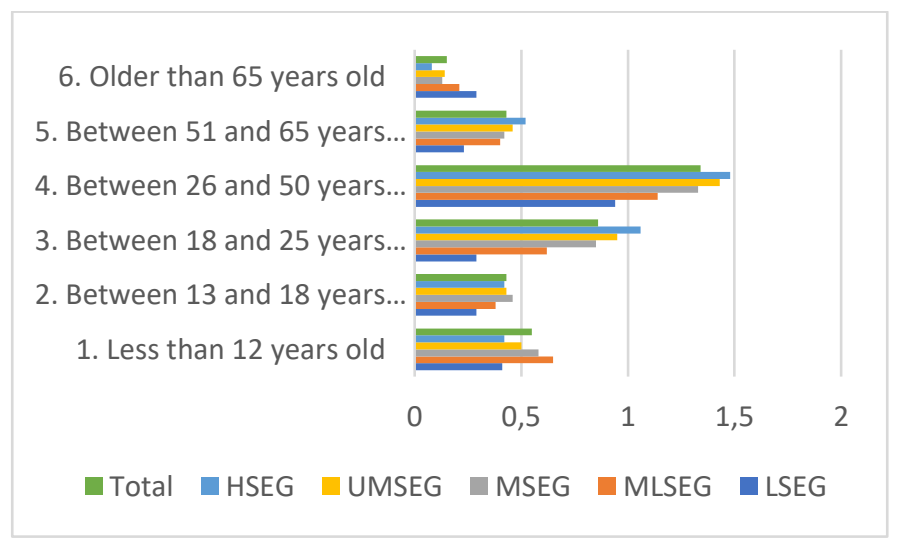

Fig. 7 Average age of family members by of socioeconomic groups.
Table 1 shows the average gender distribution along all the socioeconomic groups. In total, there are almost the same quantity of men and women per household. There is a much significant difference for LSEG and MLSEG households. LSEG present more male than female $(1,41$ vs 1,06$)$ and MLSEG instead, show more women than men $(1,86$ vs 1,54$)$.

TABLE I

AVERAGE GENDER DISTRIBUTION AMONG SOCIOECONOMIC GROUPS

\begin{tabular}{|c|c|c|c|c|c|c|}
\hline \multirow{2}{*}{ Gender } & \multicolumn{7}{|c|}{ SOCIO-ECONOMIC GROUP } \\
\cline { 2 - 7 } & LSEG & MLSEG & MSEG & UMSEG & HSEG & Total \\
\hline Male & 1,41 & 1,54 & 1,82 & 1,93 & 1,96 & 1,82 \\
\hline Female & 1,06 & 1,86 & 1,96 & 1,97 & 2,02 & 1,95 \\
\hline Total & 2,47 & 3,40 & 3,77 & 3,90 & 3,98 & 3,77 \\
\hline
\end{tabular}

In Table 2 we can see the average education level distribution among socioeconomic groups, where most households have members who have graduated or are currently studying high school. An important difference between social classes can be seen in the number of members with $4^{\text {th }}$ degree education level, HSEG show that 0,33 members have this degree whilst LSEG show a value of cero. But, having more educated people does not necessarily mean that these households will behave more sustainable.

TABLE II

AVERAGE EDUCATION LEVEL DISTRIBUTION AMONG SOCIOECONOMIC GROUPS

\begin{tabular}{|c|c|c|c|c|c|c|}
\hline & HSEG & UMSEG & MSEG & MLSEG & LSEG & TOTAL \\
\hline $\begin{array}{c}\text { Primar } \\
\text { y } \\
\text { School }\end{array}$ & 0,36 & 0,57 & 0,82 & 1,12 & 1,24 & 0,76 \\
\hline $\begin{array}{c}\text { High } \\
\text { School }\end{array}$ & 1,32 & 1,57 & 1,90 & 1,69 & 1,00 & 1,72 \\
\hline $\begin{array}{c}\text { Techno } \\
\text { logy }\end{array}$ & 0,23 & 0,26 & 0,22 & 0,12 & 0,12 & 0,21 \\
\hline $\begin{array}{c}\text { Bachel } \\
\text { or }\end{array}$ & 1,63 & 1,30 & 0,65 & 0,28 & 0,06 & 0,86 \\
\hline $\begin{array}{c}\text { Master } \\
\text { /PhD }\end{array}$ & 0,33 & 0,07 & 0,02 & 0,00 & 0,00 & 0,05 \\
\hline Neither & 0,12 & 0,13 & 0,16 & 0,19 & 0,06 & 0,15 \\
\hline Total & 3,98 & 3,90 & 3,77 & 3,40 & 2,47 & 3,77 \\
\hline
\end{tabular}

In Fig. 8 we can observe the salary range by socioeconomic groups. The figure lets notice that most houses gain between 391,00 and 750,00 USD. HSEG houses show that salaries are between 2250,00 and 5000,00 USD and LSEG appreciate a salary of less than 390,00 USD.

$17^{\text {th }}$ LACCEI International Multi-Conference for Engineering, Education, and Technology: "Industry, Innovation, And Infrastructure for Sustainable Cities and Communities", 24-26 July 2019, Jamaica. 


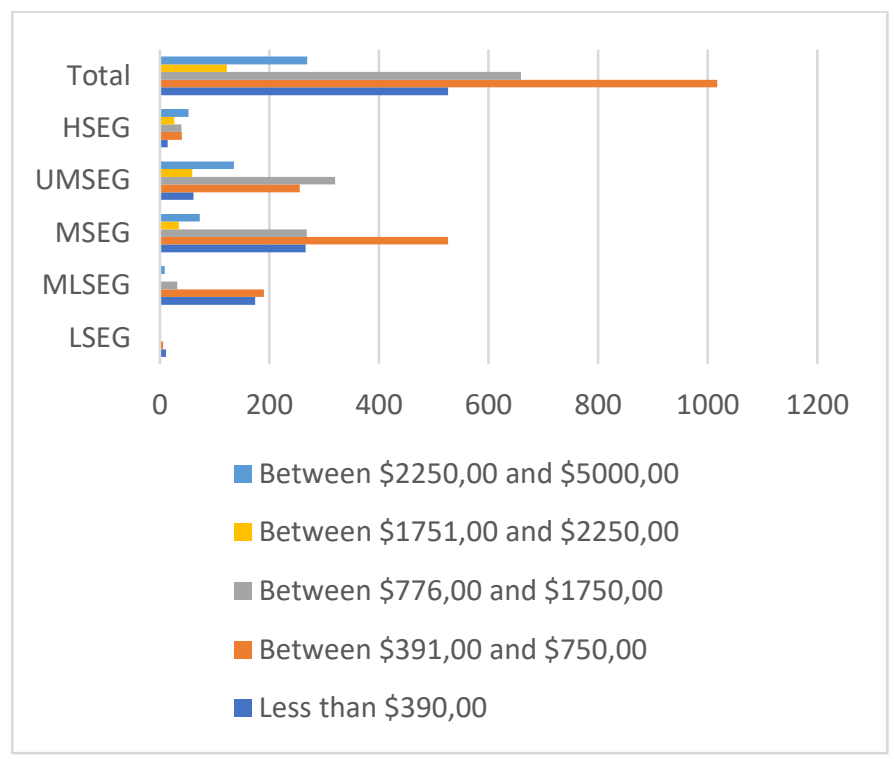

Fig. 8 Range of salaries by socioeconomic groups.

\section{Household sustainability use of electricity}

From figures 9 to 13 , we can see the pattern of sustainable behavior attitudes that affect the electricity consumption of a household. Although responses don't really vary from group to group, there is still a lack of environmental consciousness, since in theory HSEG have the highest level of education and give practically the same tendency than the LSEG. The biggest difference can be seen in question 6, in the ownership of energy saving devices. Logically, HSEG have higher capacity to acquire better technology, but they tend to also spend more energy because they can afford it.

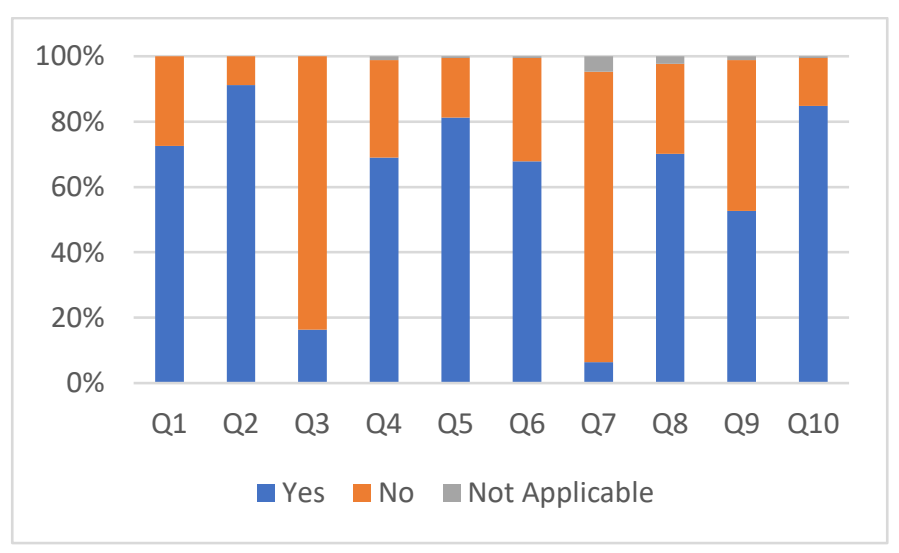

Fig. 9 Household Electricity Sustainability - HSEG.

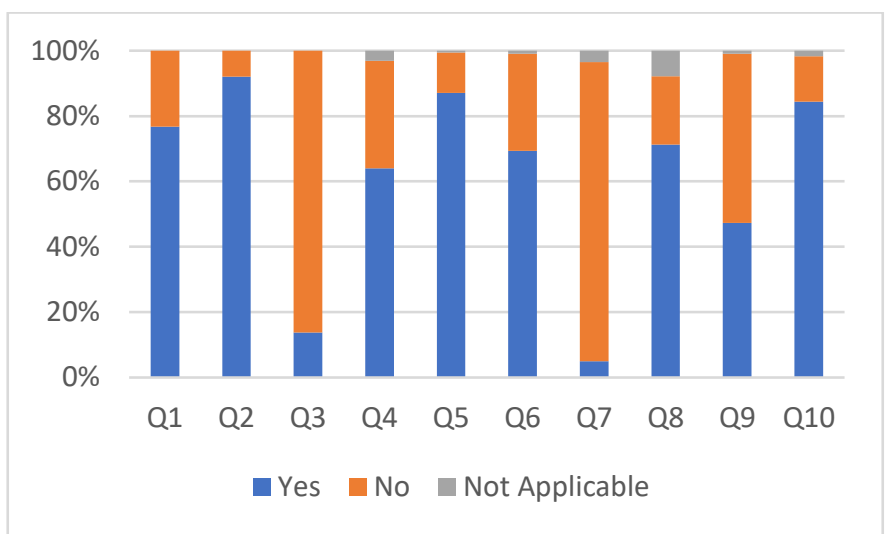

Fig.10 Household Electricity Sustainability - UMSEG.

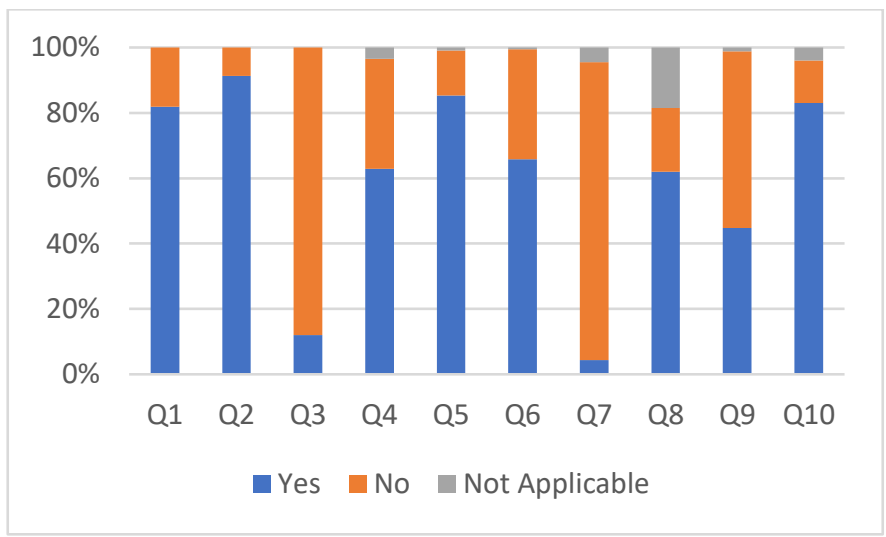

Fig. 11 Household Electricity Sustainability - MSEG.

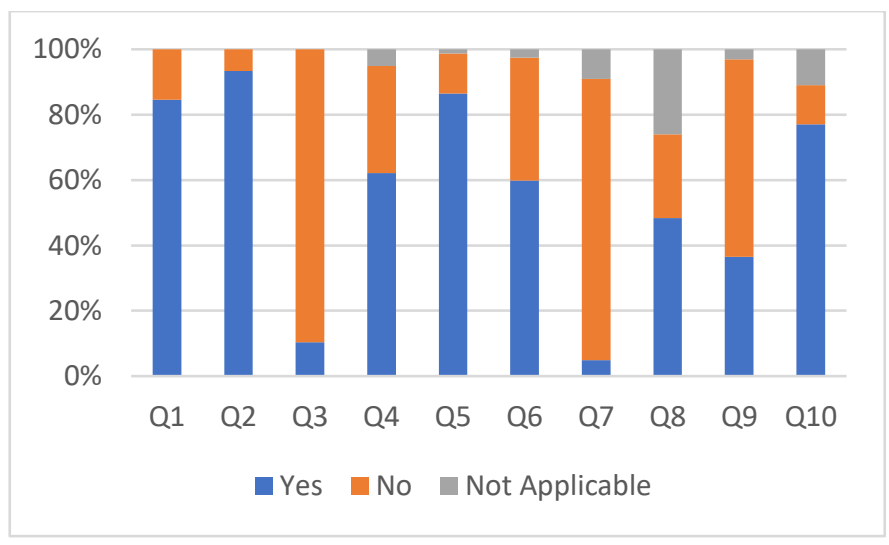

Fig. 12 Household Electricity Sustainability - MLSEG.

$17^{\text {th }}$ LACCEI International Multi-Conference for Engineering, Education, and Technology: "Industry, Innovation, And 


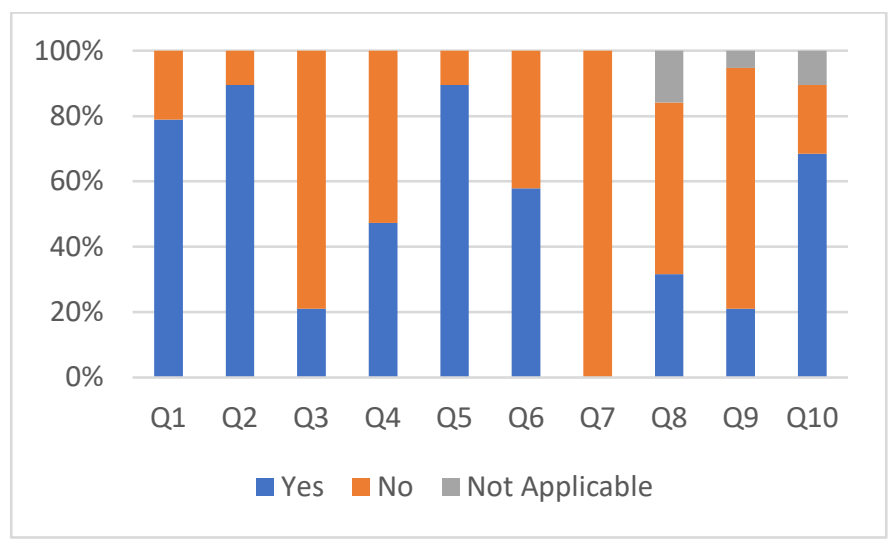

Fig. 13 Household Electricity Sustainability - LSEG.

In total, from the 2593 households, $80 \%$ affirm to disconnect their electronic devices when they're not using them or leaving the room. $92 \%$ say they turn off the lights after leaving a room. $87 \%$ claim to not introduce hot meals in the fridge. $63 \%$ iron as many clothes as possible at once and have energy saving devices; also $86 \%$ open the curtains to take advantage of sunlight and only $5 \%$ possess solar panels.

\section{Household sustainability use of water}

From figures 14 to 18 , we can see the pattern of sustainable behavior attitudes that affect the water consumption of a household. We can see the same tendency from questions 11 to 18 in the HSEG, UMSEG and MSEG households. The MLSEG and LSEG show different behavior especially in questions 13 and 17. For question about the ownership of a double flush toilet, only $16 \%$ of MLSEG say they have them against $36 \%$ for the rest of the upper classes, and none of the LSEG houses have one. Also, for question about whether they close the water faucets or not, all LSEG households answered they do.

In total, from all surveyed households, $38 \%$ affirm to reuse the waste water for other activities such as floor cleaning. 55\% use a bucket instead of a hose to water their garden or washing their vehicles. Almost 57\% take less than 10 minutes showers and only $37 \%$ check their water pipes regularly. This is important, given that water in the city of Guayaquil has some silica that adheres to the wall pipes and reduce their diameter. Also $20 \%$ of all houses have water jet economizers, logically being the most in the HSEG households.

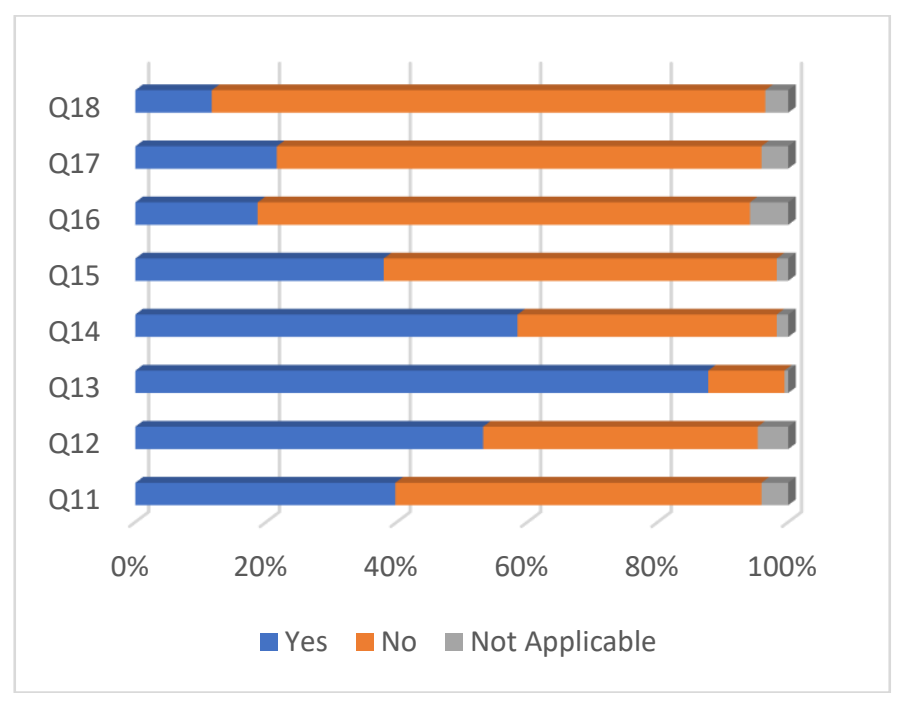

Fig. 14 Household Water Sustainability - HSEG.

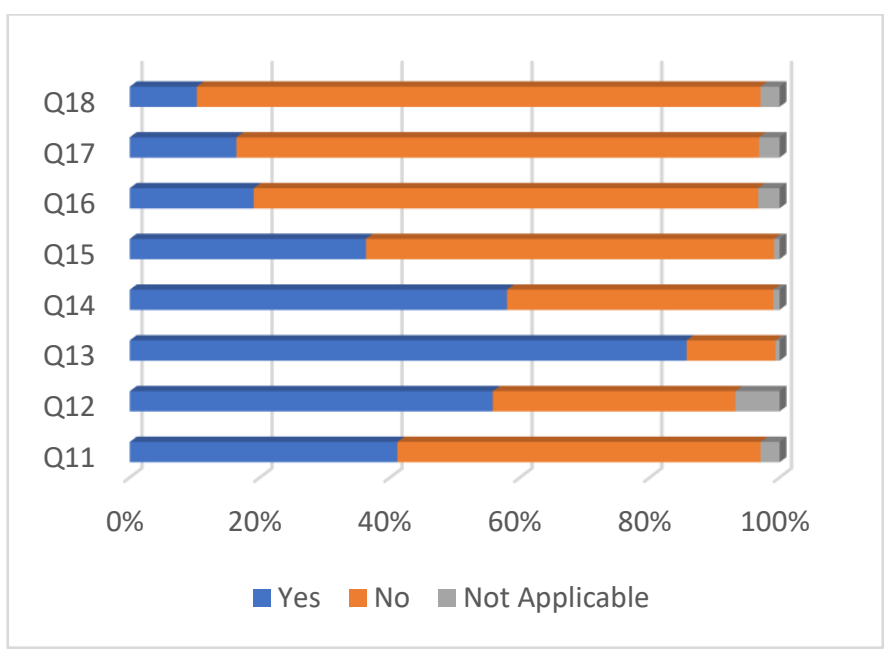

Fig. 15 Household Water Sustainability - UMSEG.

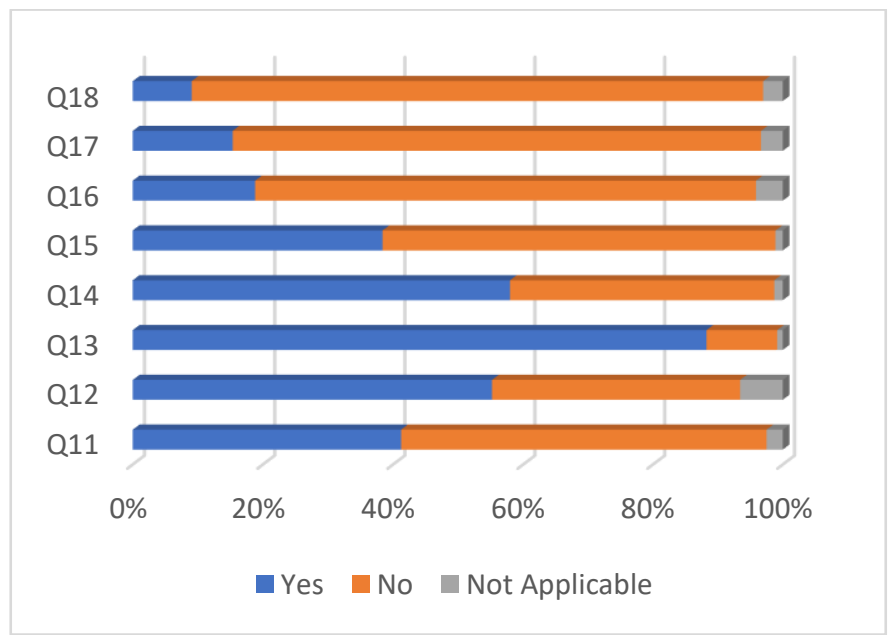

Fig. 16 Household Water Sustainability - MSEG.

$17^{\text {th }}$ LACCEI International Multi-Conference for Engineering, Education, and Technology: "Industry, Innovation, And Infrastructure for Sustainable Cities and Communities", 24-26 July 2019, Jamaica. 


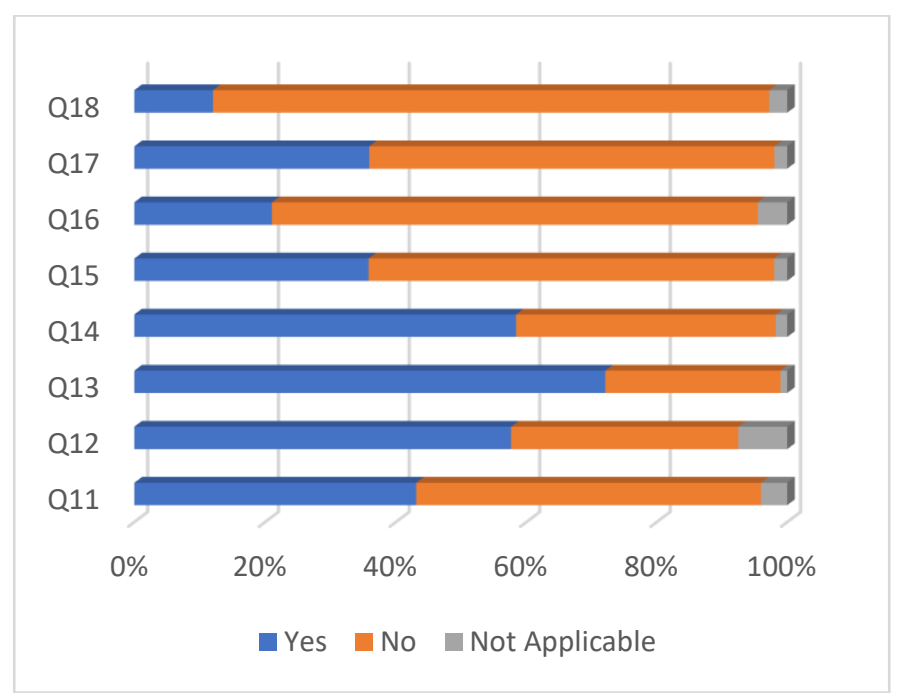

Fig. 17 Household Water Sustainability - MLSEG.

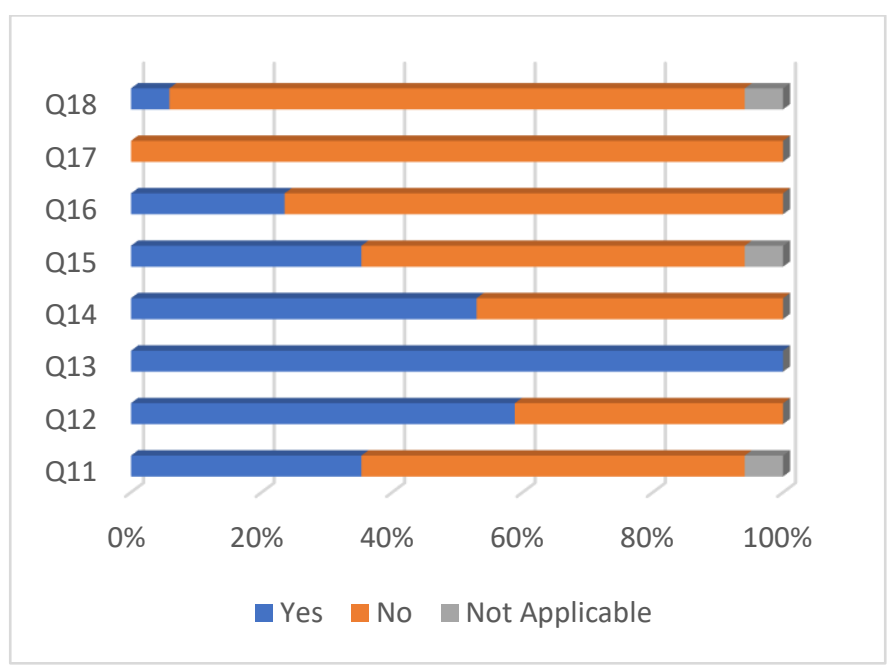

Fig. 18 Household Water Sustainability - LSEG.

\section{Household waste generation sustainability}

Figure 19 presents the household waste separation. Only the LSEG all answered that they did in fact separate all their waste. The other social groups have pretty much the same tendency for this question. The reasons why some households don't recycle are shown in figure 20. The principal reason is that there are no specific containers for each type of waste, followed by that some of them are not interested or don't know hoy to classify.

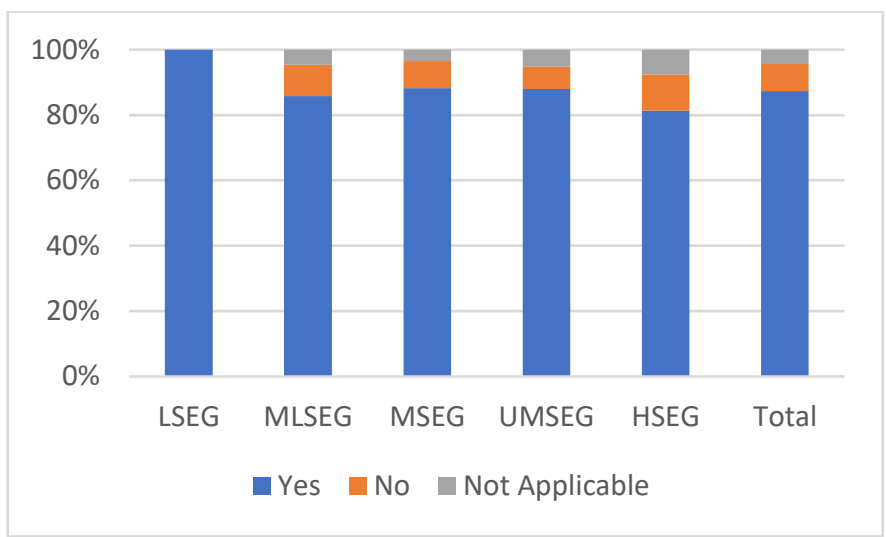

Fig. 19 Household waste separation at home.

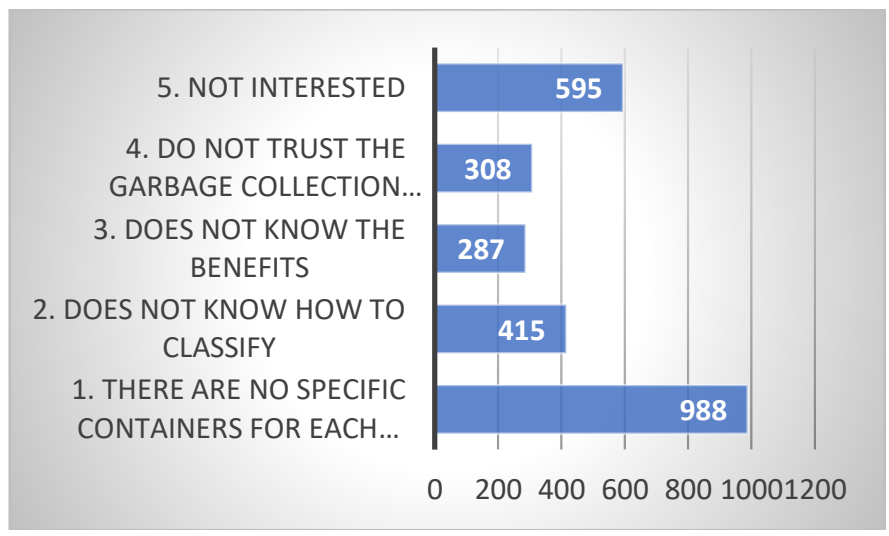

Fig. 20 Principal reason why households don't classify.

Figure 21 presents the type of meals that household acquire, 59\% buy fresh food, whilst $37 \%$ by both fresh and canned, leaving only $4 \%$ that get precooked and canned food. This indicator shows variations among socioeconomic groups, increasing the indicator of precooked meals for HSEG and the fresh food for LSEG houses. This is important, because most precooked food comes in plastic or metal containers producing non-biodegradable waste which is more harmful for the environment.

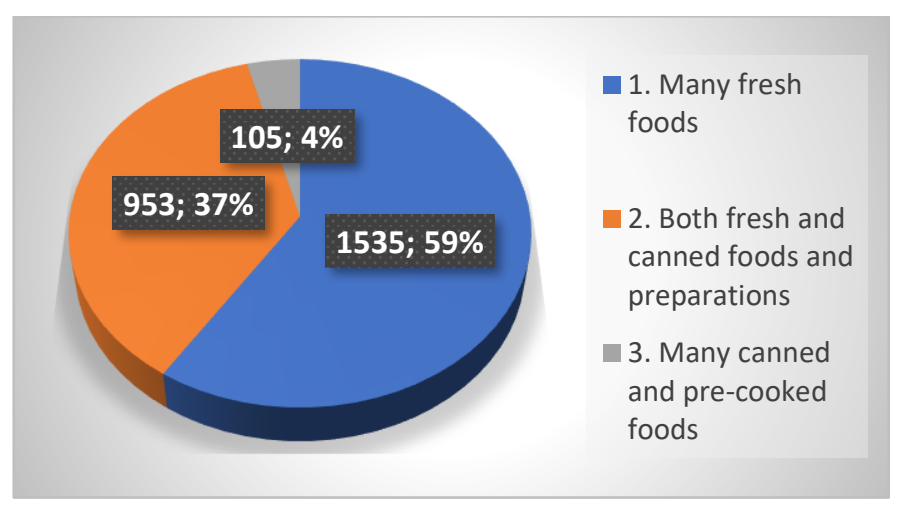

Fig. 21 Types of food consumed by households.

$17^{\text {th }}$ LACCEI International Multi-Conference for Engineering, Education, and Technology: "Industry, Innovation, And Infrastructure for Sustainable Cities and Communities”, 24-26 July 2019, Jamaica. 
Table 3 and figure 22 present the predisposition of each household to produce organic paper waste. In the table we can see a normal distribution with the amount of physical newspaper received at home. This is perhaps because of the easy access for HSEG households to online news. In the figure it's shown the frequency of catalogs, magazines and advertisements that arrive each week. This type of organic waste is more harmful because of the type of paper and ink used.

TABLE III

HOUSEHOLD NEWSPAPER RECEPTION

\begin{tabular}{|c|c|c|c|c|c|c|}
\hline \multirow{2}{*}{ Frequency } & \multicolumn{7}{|c|}{ SOCIO-ECONOMIC GROUP } \\
\cline { 2 - 7 } & $\begin{array}{c}\text { LSE } \\
\text { G }\end{array}$ & $\begin{array}{c}\text { MLSE } \\
\text { G }\end{array}$ & $\begin{array}{c}\text { MSE } \\
\text { G }\end{array}$ & UMSEG & HSEG & Total \\
\hline $\begin{array}{c}\text { One Daily } \\
\text { only }\end{array}$ & 1 & 32 & 140 & 130 & 38 & 341 \\
\hline $\begin{array}{c}\text { Only the } \\
\text { Sunday } \\
\text { Newspaper }\end{array}$ & 0 & 48 & 115 & 108 & 20 & 291 \\
\hline None & 16 & 327 & 913 & 592 & 113 & 1961 \\
\hline
\end{tabular}

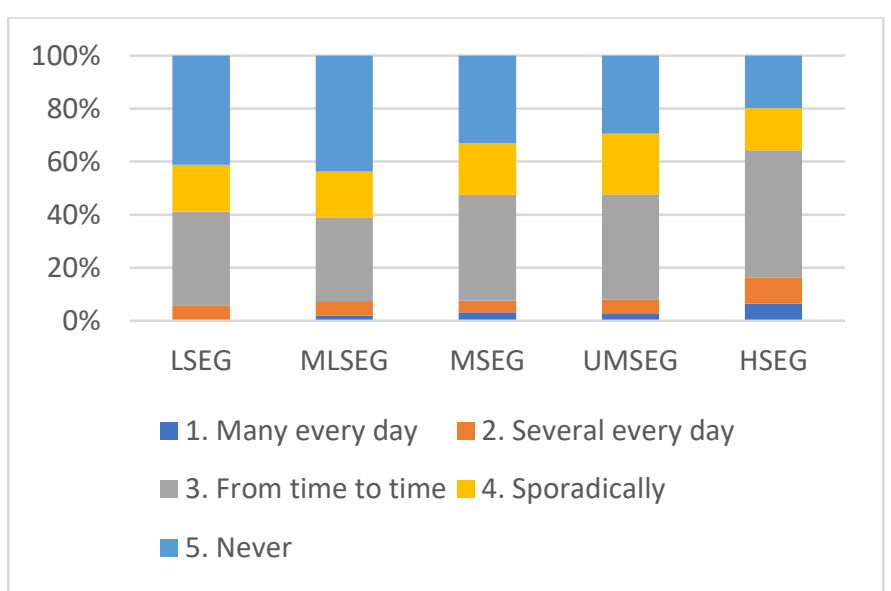

Fig. 22 Frequency of catalogs, magazines and advertising by socioeconomic group.

Figure 23 presents the household weekly nonbiodegradable waste generation for plastic, metal and cardboard. Almost $60 \%$ of homes acquire many glass bottles, jars and containers every week whilst $20 \%$ of them get brick containers. Between $40 \%$ and 55\% buy food and beverages in plastic bags, pots, jars and tubs, and 50\% get many metal beverage and food containers.

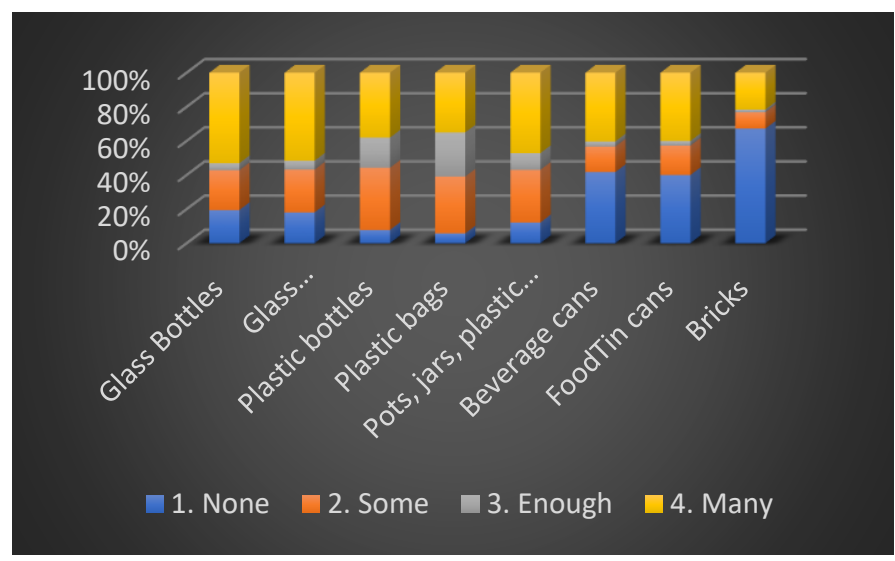

Fig. 23 Household weekly non-biodegradable waste generation.

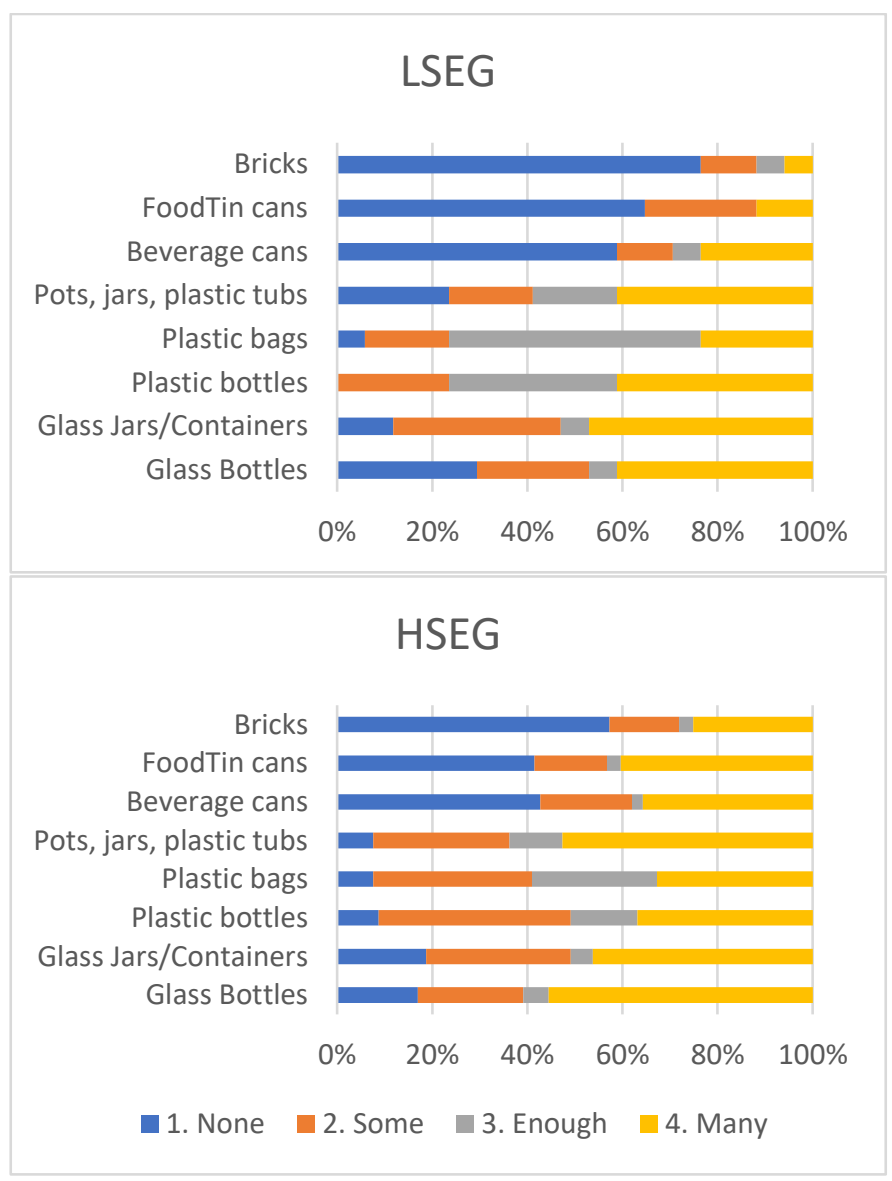

Fig. 24 Household weekly non-biodegradable waste generation comparison among high and low socioeconomic groups.

Figure 24 compares the habits of generation of waste between HSEG and LSEG households. As expected, the tendency shows that high income households produce more this type of wastes than low income ones. Low income houses buy more fresh food in the local markets instead.

$17^{\text {th }}$ LACCEI International Multi-Conference for Engineering, Education, and Technology: "Industry, Innovation, And 


\section{CONCLUSIONS}

This study aimed to analyze the current household behavior towards sustainable resource consumption and waste generation, and its relationship with various socioeconomic characteristics of the city, such as social status.

The number of members per household increase with social status from 2,47 to 3,98. Most houses have a minimum of high school level, showing that $4^{\text {th }}$ degree members locate at the higher social groups. The income level of most homes is between $\$ 391,00$ and $\$ 750,00$ and the age range is from 26 to 50 years old.

The results suggested that different socioeconomic groups houses demonstrate the same tendency in the sustainable consumption attitudes of electricity of water. Only significant differences are found in the possession of ecological devices. HSEG possess more these kinds of devices than LSEG.

Moreover, the solid waste composition exhibits different characteristics for different socioeconomic statuses. That means that the peoples' socioeconomic status (usually measured by a combination of education, income and occupation) is a determining factor for solid waste generation rates and composition.

Finally, it's cleared in this research that people that live in the city don't really care for the environment [15]. There is a lack of environmental consciousness and even the level of income and education don't affect this awareness. This may be an effect on the low tariffs of electricity and water and also that there really isn't bad advertisement for open dumps and landfills since the communication powers ally with the local municipality.

\section{ACKNOWLEDGEMENTS}

This work was supported by students from Universidad de Guayaquil and Universidad Politecnica Salesiana from the city of Guayaquil.

\section{REFERENCES}

[1] Morales Ramírez, D., Alvarado Lagunas, E., \& Picazzo Palencia, E. (2015). Actitudes y Creencias del Consumo de Energía Eléctrica en los Hogares: Caso aplicado al Área Metropolitana de Monterrey. M+A. Revista Electrónica de Medioambiente, 16(1).

[2] Sharholy, M., Ahmad, K., Mahmood, G., \& Trivedi, R. C. (2008). Municipal solid waste management in Indian cities - A review. Waste Management, 28(2), 459-467.

[3] Suthar, S., \& Singh, P. (2015). Household solid waste generation and composition in different family size and socio-economic groups: A case study. Sustainable Cities and Society, 14, 56-63.

[4] Constituyente, A. (n.d.). Constitución de la República del Ecuador. Retrieved from https://www.wipo.int/edocs/lexdocs/laws/es/ec/ec030es. pdf.
[5] Instituto Nacional de Estadísticas y Censos. (2017). Estadística Ambiental Económica en Gobiernos Autónomos Descentralizados Municipales: Gestión de Residuos 2016.

[6] Hidalgo J., (2019). Influence of socio-economic factors on household solid waste (HSW) generation of the city of Guayaquil, Ecuador. 17th LACCEI International Multi-Conference for Engineering, Education, and Technology: "Industry, Innovation, And Infrastructure for Sustainable Cities and Communities", 24-26 July 2019, Jamaica.

[7] Palmborg, C. (1986). Social habits and energy consumption in singlefamily homes. Energy, 11(7), 643-650. doi:10.1016/0360-5442(86)901441

[8] Gram-Hanssen, K. (2011). Households' energy use - which is the more important: efficient technologies or user practices? World Renewable Energy Congress, Sweden.

[9] Hidalgo J., C. S. (2018). The Determinants of Household Electricity Demand in Marginal Ecuador: "A Case Study at Monte Sinai". 16th LACCEI International Multi-Conference for Engineering, Education, and Technology: "Innovation in Education and Inclusion.

[10] Ebru Acuner, M. Ö. (2018). "A review on household energy consumption behavior: how about migrated consumers?". Environmental Economics, Volume 9, Issue 4.

[11]Sustainable water usage systems: Models for the sustainable utilization of domestic water in urban areas. (1999). Water Science and Technology, 39(5).

[12]Willis, R. M., Stewart, R. A., Giurco, D. P., Talebpour, M. R., \& Mousavinejad, A. (2013). End use water consumption in households: impact of socio-demographic factors and efficient devices. Journal of Cleaner Production, 60, 107-115.

[13]J.-G. Lu, "Title of paper with only the first word capitalized," J. Name Stand. Abbrev., in press.

[14]Y. Yorozu, M. Hirano, K. Oka, and Y. Tagawa, "Electron spectroscopy studies on magneto-optical media and plastic substrate interface," IEEE Translated J. Magn. Japan, vol. 2, pp. 740-741, August 1987 [Digest $9^{\text {th }}$ Annual Conf. Magnetics Japan, p. 301, 1982].

[15]M. Young, The Technical Writer's Handbook, Mill Valley, CA: University Science, 1989.

[16]Bandara, N. J. G. J., Hettiaratchi, J. P. A., Wirasinghe, S. C., \& Pilapiiya, S. (2007). Relation of waste generation and composition to socio-economic factors: a case study. Environmental Monitoring and Assessment, 135(13), 31-39.

[17]Trang, P. T. T., Dong, H. Q., Toan, D. Q., Hanh, N. T. X., \& Thu, N. T. (2017). The Effects of Socio-economic Factors on Household Solid Waste Generation and Composition: A Case Study in Thu Dau Mot, Vietnam. Energy Procedia, 107, 253-258.

[18]Jonas Petro Senzige, Daniel Oluwole Makinde, Karoli Nicolas Njau, Yaw Nkansah-Gyeke. Factors Influencing Solid Waste Generation and Composition in Urban Areas of Tanzania: The Case of Dar-es-Salaam. American Journal of Environmental Protection. Vol. 3, No. 4, 2014, pp. $172-17$

[19]Suthar, S., \& Singh, P. (2015). Household solid waste generation and composition in different family size and socio-economic groups: A case study. Sustainable Cities and Society, 14, 56-63.

$17^{\text {th }}$ LACCEI International Multi-Conference for Engineering, Education, and Technology: "Industry, Innovation, And Infrastructure for Sustainable Cities and Communities", 24-26 July 2019, Jamaica. 